\title{
THE NORMATIVE STANDING OF ACCESS TO JUSTICE: AN ARGUMENT FROM NON- DOMINATION
}

\author{
William Lucy*
}

After elucidating and defending an account of access to justice that is consistent with most uses of that notion in academic and policy discourse, this essay examines some arguments that attempt to show the value of access to justice. It shows that one such argument (from non-domination) does a better job of illustrating access to justice's normative significance than two frequently invoked competitors (the arguments from the rule of law and equality). In an era in which access to justice seems genuinely in peril, it is vital to appreciate the normative cost of its restriction or denial.

\begin{abstract}
Après avoir expliqué de manière éclairante et défendu une définition de l'accès à la justice qui colle à la plupart des utilisations qu'on fait de cette expression dans le discours universitaire et politique, l'auteur de cet essai se penche sur certains arguments qui tentent de démontrer la valeur de l'accès à la justice. Il montre qu'un de ces arguments (la non-domination) illustre mieux la signification normative de l'accès à la justice que deux autres "concurrents » fréquemment invoqués (la primauté du droit et l'égalité). À une époque où l'accès à la justice semble vraiment en péril, il est capital de comprendre le coût normatif de la restriction de l'accès à la justice ou de son refus.
\end{abstract}

"Why all this ruckus about such a pipsqueak issue as court fees?"1

What do we mean when we speak of access to justice? Why, if at all, should that notion be thought valuable? These two questions are the fulcrum of this article. The first occupies Part I, which offers an account of the nature of access to justice that both captures some of its complexities and is consistent with most usages of the notion in academic and policy discourse. Part II addresses the second, albeit in a limited way. After outlining, in section A, what is involved in showing the value of access to justice, it examines in section B just one substantive argument - from non-domination - to that end. Part II is therefore merely one step in a properly general response to the second question, which would consider all plausible answers to that question. While limited in that way, Part II nevertheless aspires to show the interest and fecundity of the argument from non-domination. Furthermore, although this part makes no effort to discredit all other answers to the second question, it does demonstrate that the argument from

\footnotetext{
* William Lucy, Law School, University of Durham; email: w.n.lucy@durham.ac.uk. Thanks for comments, help, and advice to Daniel Attenborough, Phil Handler, Hector MacQueen, Deirdre McCann, John Murphy, and Alexander Williams. Nothing here is their fault. I also owe a debt of thanks to the editors and reviewers of the Yearbook for their assiduous work.

1 Frank Michelman, "The Supreme Court and Litigation Access Fees: The Right to Protect One's Rights - Part One" 1973 Duke LJ 1153 at 1163.
} 
non-domination performs better than a pair of more popular responses to the second question. They are the arguments from the rule of law and from equality, which are examined in section $\mathrm{C}$.

Why these questions and why now? There are at least two reasons. First, and most obviously, because the costs associated with access to justice have been and are a pressing political issue in many of the common law jurisdictions. ${ }^{2}$ Governments with economic austerity measures in mind have sought out many areas of public expenditure for reduction, legal aid and cognate budgets being among them. They have suffered accordingly. The reduction of funding to provincial governments has resulted in the erosion or eradication of funding for (usually free) legal advice centres. In England and Wales, the process of paring back central and local government funding for legal advice and representation, combined with significant increases in court fees, has met considerable criticism. Among critics, some lawyers have portrayed this process as being unfair, putting recourse to law beyond the reach of all but the wealthy. ${ }^{3}$ To assess complaints such as these presupposes some sense of the value access to justice might have. This article examines one such value.

The second reason arises from the fact that, even if access to justice were not a pressing political issue, its alleged normative significance would still be worthy of juristic attention. For this feature of legal institutional design, like any other, should be examined in relation to its supposed point or value. Lawyers and jurists rightly spend a good deal of time considering the point, purpose, or value of a wide

2 For England and Wales, see the sources in note 3 below for a taster of the contemporary controversy, and, for an overview of government proposals from 2010, see Roger Smith, "Middle Income Access to Justice: Implication [sic] of Proposals for the Reform of Legal Aid in England and Wales" in Michael Trebilcock, Anthony Duggan \& Lorne Sossin, eds, Middle Income Access to Justice (Toronto: University of Toronto Press, 2012) 173. Jennifer Graham “Access to Justice in Canada 'Abysmal' CBA Report,"The Star (18 August 2013), online:

$<$ http://www.thestar.com/news/canada/2013/08/18/access_to_justice_in_canada_abysmal_cba_report.html $>$ provides an introduction to the debate in Canada while, for Australia, see Productivity Commission 2014, Inquiry Report No 72, "Access to Justice Arrangements" ( ${ }^{\text {rd }}$ December 2014), online: < http://www.pc.gov.au/inquiries/completed/accessjustice/report> and Australian Government, Attorney-General's Department, Access to Justice Taskforce, "A Strategic Framework for Access to Justice in the Federal Civil Justice System” (Barton, ACT: Commonwealth of Australia, 2009), online: <https:/www.ag.gov.au/LegalSystem/Documents/A\%20guide\%20for\%20future\%20action.pdf>.

Were access to justice not a live political issue in these and other jurisdictions, it would be difficult to explain the fact that, as of 2010, there had been twenty-three national surveys on the topic since 1993, the majority taking place between 2001 and 2010. Pascoe Pleasence \& Nigel Balmer, "Caught in the Middle: Justiciable Problems and the Use of Lawyers," in Trebilcock, Duggan \& Sossin, ibid, 30.

3 Public protest by practising lawyers in England and Wales is uncommon, yet the enactment of the Legal Aid, Sentencing and Punishment of Offenders Act 2012, 2012, c 10 [LASPO] provoked a good deal of it. See Conor Gearty, "Legal Aid Changes," online: <http://ukconstitutionallaw.org/2013/06/10/conor-gearty-legal-aid-changes/>; Owen Bowcott and Nicola Brown, "More Than 1,000 Lawyers Protest Outside Parliament at Legal Aid Cuts," The Guardian (7 May 2014), online: <http:/www.theguardian.com/law/2014/mar/07/lawyers-protest-parliament-legal-aid-cuts>; Owen Bowcott, "Barristers Vote to Join Solicitors' Legal Aid Protest," The Guardian (15 July 2015), online: $<$ http://www.theguardian.com/law/2015/jul/15/barristers-vote-to-join-solicitors-legal-aid-protest $>$. For a recent indictment of British government changes to access to justice, see the report of the House of Commons Justice Committee, "Courts and Tribunals Fees: Second Report of Session 2016-17," online: <http://www.publications.parliament.uk/pa/cm201617/cmselect/cmjust/167/167.pdf $>$ and the short summary in Owen Bowcott, "Steep Court Fee Rises Are a Tax on Justice, say MPs," The Guardian (20 June 2016), online: <https://www.theguardian.com/law/2016/jun/20/ministry-of-justice-urgedto-scrap-excessive-court-fees $>$. An excellent brief overview of some of the LASPO changes is Frederick Wilmot-Smith, "Necessity or Ideology?" London Review of Books (6 November 2014) at 15-17. 
range of substantive legal areas, and there is no reason why this concern should not extend to more procedural-cum-institutional aspects of the legal system like access to justice. The way the justice system operates and is organized, including the nature of the trial process, the organization of courts and related institutional forms, and the appointment and behaviour of judges, magistrates, and other system personnel is surely just as important an area of study as that system's various substantive bodies of doctrine. Furthermore, it might be that these procedural-cum-institutional aspects are more important than the latter in this sense: they are the aspects of a legal system its users encounter first. Therefore, they have an immediate effect upon a system's accessibility and utility.

This second reason takes an explicitly jurisprudential slant in what follows, and two research hypotheses explain this. The first concerns the limits of contemporary legal philosophy, which ranges over both the core questions of descriptive analytical jurisprudence, on the one hand, and normative moral and political philosophy, on the other. Chief among the questions that preoccupy analytical jurists is "what is law?" whereas some of the central questions of moral and political philosophy include "what is a good life?" and "what is justice?" Much legal philosophy in the last four decades has brought work of the latter kind to bear upon large segments of legal doctrine, the burden of such work being in part that of determining the moral and political standing of the area of law in question. The most interesting instances of such work have examined the moral and political status of, inter multos alios, constitutional, administrative, land, contract, criminal, tort, and international law. ${ }^{4}$

The questions animating this article locate it within the latter tradition, although the article attempts to extend the tradition's boundaries. For it is one thing to examine the normative basis of a complex, but broad, swathe of substantive law, such as unjust enrichment, and seemingly quite another to investigate the normative basis of an aspect of legal institutional design like access to justice. Since numerous areas of substantive law appear clearly related to many of our intuitions about right and wrong, the task of interrogating those intuitions, and of examining their alleged connections with those areas of law, looks both salient and fruitful. Access to justice, by contrast, might be such a varied and jurisdictionally specific aspect of legal institutional design that it lacks any obvious connections with moral or political intuitions. The remainder of this article challenges this view. ${ }^{5}$ It does so by examining the way in which one account of political morality can support access to justice, and, in so doing, it presents a test case for that account. If this account provides illumination here, then it might illuminate much else besides. Our narrow focus thus allows us to assess the degree of determinacy we should expect from broad and relatively abstract normative theories.

The second hypothesis begins with an observation. By far the greatest part of the access-to-justice literature concerns the identification and measurement of what was once called (unmet) legal need and what are now called (unresolved or unadvised) justiciable problems. ${ }^{6}$ This work has been vital in

4 Eg, Alan Brudner, Constitutional Goods (Oxford: Clarendon Press, 2004); Patrick Capps, Human Dignity and the Foundations of International Law (Oxford: Hart, 2009); Arthur Ripstein, Private Wrongs (Cambridge, MA: Harvard University Press, 2016); Victor Tadros, The Ends of Harm: The Moral Foundations of the Criminal Law (Oxford: Clarendon Press, 2013).

5 I am not the first to issue such a challenge. See David Dyzenhaus, "Normative Justifications for the Provision of Legal Aid" in Report of the Ontario Legal Aid Review: A Blueprint for Publicly Funded Legal Services (1997) 2 at 475-502.

6 On legal need, see BA Curran, The Legal Needs of the Public (Chicago: American Bar Foundation, 1977) at 9; Consortium on Legal Services and the Public, Legal Needs and Civil Justice: A Survey of Americans (Chicago: 
charting the very limited reach of traditional sources of legal information and advice, having also influenced policy developments in the common law world. Yet this literature has a glaring gap, to some extent explicable given its primary focus: missing is an account of why unmet legal need, or unaddressed-cum-unadvised justiciable problems, should be considered bothersome. Of course, those affected by such problems may well have prudential or self-interested reasons to worry, but what if many so affected were impervious to such reasons? Normative considerations are not primarily determined by prudence or self-interest and may thus provide an answer - or series of answers - to the question of what makes unmet legal need, or unaddressed justiciable problems, troublesome. This, then, is the payoff from bringing the empirical access-to-justice literature into contact with the kind of normative enquiry pursued here. In showing why access to justice matters, normatively speaking, this article also shows why unmet legal need or unaddressed justiciable problems matter.

\section{ACCESS TO JUSTICE: WHAT?}

When lawyers and citizens speak about access to justice, they only rarely have in mind the various political-philosophical conceptions of (mainly) distributive justice that dominate academic discourse and, occasionally, animate policy discussion. ${ }^{7}$ Most frequently, the justice in play in talk about access to justice is the justice supposedly embodied in the "justice systems" of contemporary nation-states. All of those systems, in addition to having sub-systems of "criminal justice," "civil justice," "family justice" and the like, have at least three broader or more general components that constitute the domain of access to justice. ${ }^{8}$ One concerns the production and promulgation of legal knowledge itself; another relates to guidance about that knowledge; and a third involves access to those institutional forms - usually, but not exclusively, courts and tribunals - charged with resolving disputes within justice systems.

The first and second components of access to justice are interestingly connected. In common law jurisdictions, the production and promulgation of legal knowledge is principally a matter of reporting the

American Bar Association 1994) at 8, online: <http://www.americanbar.org/content/dam/aba/migrated/legalservices/downloads/sclaid/legalneedstudy.authcheckdam.pdf $>$; Deborah Rhode, Access to Justice (New York: Oxford University Press, 2004) ch 1, which contains more than a dozen invocations of "need," all but one of them unanalyzed (at 6). The classic British studies of justiciable problems are: Hazel Genn, Paths to Justice (Oxford: Hart, 1999); Hazel Genn \& Alan Paterson, Paths to Justice Scotland (Oxford: Hart, 2001). Also important are Pascoe Pleasence et al, "Causes of Action: First Findings of the LSRC Periodic Survey" (2003) 30 J Law \& Society 11; Pascoe Pleasence, Nigel Balmer \& Alexy Buck, Causes of Action: Civil Law and Social Justice, 2d ed (London: Stationery Office, 2006). For this approach in other jurisdictions, see Ruth Sandfur, "Access to Justice: Classical Approaches and New Directions" and Ab Currie, "The Legal Problems of Everyday Life" both in (2009) 12 Sociology of Crime, Law \& Deviance ix and 1 respectively.

7 See Majorie Mayo et al, Access to Justice for Disadvantaged Communities (Bristol: Policy Press, 2015) Introduction, ch 1, 2; Roderick Macdonald, “Access to Justice and Law Reform" (1990) 10 Windsor YB Access Just 287 at 290-294. However, the norm is to invoke a non-defined notion of social justice. See Liz Curran \& MA Noone, "The Challenge of Meeting Unmet Legal Need" (2007) 21 J Law \& Social Policy 63 at 89; Richard Abel, "Law without Politics: Legal Aid under Advanced Capitalism" (1984-1985) 32 UCLA L Rev 474 at 475.

8 That these sub-systems are nowhere named "injustice" systems says something about their aspirations, if not their actual functioning. I am not the first to note this. See John Gardner, Law as a Leap of Faith (Oxford: Clarendon Press, 2012) at 238. 
decisions of courts in contested cases, on the one hand, and the publication of the outputs of the legislative process, in the form of statutes and related instruments, on the other. That is the law. Legal knowledge in these jurisdictions therefore consists of case law and statute law as well as the rich bodies of technically demanding commentary upon both that we find in legal textbooks and other forms of juristic analysis. Since statutes and case reports in electronic form are now easily available to all with Internet access in the common law jurisdictions, most citizens are therefore able to acquaint themselves with the law. That cases (in the form of law reports) and statutes should be easily publicly available follows from one requirement of the rule of law ideal. For, whatever else that ideal entails, it certainly requires that laws be published; only then will addressees of the law know what is required of them and only then can law function as a means of subjecting human conduct to the governance of rules. ${ }^{9}$ For obvious reasons, this first component of access to justice can be labelled the "legal knowledge (LK) component."

Since legal knowledge, in the form of law reports and statutes, is so easily available, one may wonder why the second component of access to justice is necessary. ${ }^{10}$ If the law is accessible to all, why is guidance needed about what it requires? Posing the question shows, for lawyers at least, its naivety. Legal knowledge is complex. Why? If we set aside a sceptical explanation - that the law's complex (or recondite or esoteric) nature is a consequence of its guardianship by a professional elite seeking to maintain its power and expertise - what non-sceptical grounds could account for this? Some degree of complexity surely arises from the fact that current legal knowledge draws upon a long tradition and rich vocabulary of legal concepts that do not always overlap with ordinary common-sense concepts. Moreover, even when legal concepts have direct equivalents in ordinary language and thought - think, for example, of causation or intention, reasonableness and loss - the apparent correspondence is sometimes far from exact. One reason for this is that legal concepts have to withstand more weight and stress than their non-legal equivalents, being subject to forensic scrutiny where the stakes are very high indeed. One's life or one's liberty might depend upon whether a judge and a jury thinks one "intended" $\mathrm{X}$ as opposed to $\mathrm{Y}$. In that context, it will come as no great surprise if the legal conception of intention departs in some aspects from its non-legal equivalent.

In addition, there appear to be some legal concepts that either have no analogues in ordinary understanding, or, when they do, the legal counterpart is esoteric. The notion of ownership is an important part of our ordinary, everyday conception of the world that must, with regard to estates in land in England at least, be converted into the "fee-simple absolute in possession." The latter, of course, is far removed from our ordinary understanding of full ownership, yet it is a bedrock principle of land law. The actus reus requirement for most serious crimes is a similarly fundamental principle within criminal law that, although easily translatable into a common-sense equivalent, has often been treated opaquely by common lawyers. On issues like these, lawyers speak a different and more exotic language than ordinary people, part of the lawyerly role in this situation being to act as translator. Lawyers also offer a related translation service, from recondite complexity to simplicity, if and when there are areas of law

9 See LL Fuller, The Morality of Law, revised ed (New Haven, CT: Yale University Press, 1969) at 74.

10 For one who had this thought some time ago, see Richard Susskind, The Future of Law: Facing the Challenges of Information Technology (Oxford: Oxford University Press, 1996); Richard Susskind, The End of Lawyers? Rethinking the Nature of Legal Services (Oxford: Oxford University Press, 2008). 
that are intellectually very difficult. Difficulty could arise from volume, in the sense that some areas of law may be "bittier" than others, such as when, for instance, there are numerous overlapping sources of law (cases, statutes, statutory instruments, and supra-national rules), all of which have to be regularly and consistently combined. Or it may arise just because the concepts and ideas in play are hard to understand (although there is no obvious means by which we could assess the latter).

Another reason why complexity marks legal knowledge concerns the process of integrating current legal developments into the narrative of existing and past law. Newly decided cases rarely make the preexisting cases in that area of law redundant; similarly, new statute law does not often eradicate the preexisting law in some area and start completely anew with a clean slate. ${ }^{11}$ Almost all current legal developments are cognisant of the law that has gone before and usually re-evaluate some aspects of that law. The animating idea is that the law as a whole, as well as its particular doctrinal departments, is, or should strive to be, a coherent system. One aspect of legal complexity thus arises from this aspiration, since the job of integrating current legal developments into the narrative of recent and more ancient legal history is not always straightforward. That seems particularly likely with regard to areas of law that are voluminously "bitty" in the sense noted in the previous paragraph.

Before turning to the third component of access to justice, note also that none of these causes of legal complexity, nor the rationale they provide for legal expertise, are themselves necessary. By this I mean that there is nothing obvious about either legal systems in general, or the idea of law itself, that means that they, and it, must be complicated (or esoteric or recondite). Law and legal systems can surely be simple, complex, or some combination of the two, yet those of us who live in complex legal systems should not assume that this is a necessary or normal state for all law and legal systems. Levels of legal complexity are surely related to levels of social, economic, and cultural complexity, but the link or links here are themselves seemingly complex. ${ }^{12}$ For present purposes, it is sufficient to note that legal complexity makes access to legal expertise necessary. This second component of access to justice is labelled the "legal expertise (or LE) component."

The third component of access to justice is access to those bodies - courts and related institutional forms - that constitute the primary dispute resolution fora of most justice systems. Besides explicitly discriminatory provisions ("whites only"), the most obvious way in which access to courts and cognate institutions can be limited is via charges for use. Modest charges are unlikely to cause difficulty, provided "modest" is determined by reference to factors such as average levels of income and wealth in the society in question. Yet such charges must also, if they are not to exclude the worst-off from accessing the court system, be constructed so as to be sensitive to cases of specific hardship. ${ }^{13}$ Those

11 Even ostensibly bold legislative changes often draw upon previous law: the Consumer Rights Act 2015, 2015, c 15, is a recent instance in England and Wales, an older example being the Occupiers' Liability Act 1957, 1957, c 31. See Patrick Atiyah, "Common Law and Statute Law" (1985) 48 Mod L Rev 1; Jack Beatson, "Has the Common Law a Future?" (1997) 56 Camb LJ 291; Andrew Burrows "The Relationship between Common Law and Statute in the Law of Obligations" (2012) 128 Law Q Rev 232 for reflections on the general issue.

12 For a complex account of various social system "couplings" and "linkages," see Niklas Luhmann, Social Systems (Palo Alto, CA: Stanford: Stanford University Press, 1996); Niklas Luhmann, "Operational Closure and Structural Coupling: The Differentiation of the Legal System" (1992) 13 Cardozo L Rev 1419.

13 This being the view of Canadian and English courts in civil cases. See Trial Lawyers Association of BC and Canadian Bar Association v AG of BC, [2014] SCC 59 [Trial Lawyers]; $R$ v Lord Chancellor, Ex parte Witham, [1998] QB 575 
unable to afford modest court fees must not be excluded from the court system, at least not if the justice system is indeed open to all. However, the issue of payment for the use of courts raises an important question - namely, why are such charges imposed and thought appropriate? If legal systems with dispute resolution structures like courts and related institutional forms are indeed impure public goods, as some economists and social choice theorists claim, then the imposition of a full-cost recovery regime upon litigants in some jurisdictions is obviously problematic. ${ }^{14}$ Such a regime in effect transforms an impure public good into a private good. Modest court fees do not have such a radical effect and might be justified, for example, as a means of deterring precipitate recourse to the courts. This third component of access to justice is dubbed the "legal fora (or LF) component."

For current purposes, "access" in "access to justice" bears its ordinary meaning. Access is therefore a matter of degree: it can be difficult, easy, or anything in between. Moreover, the degree of access to the three components of access to justice might differ according to the component in question. We could imagine legal systems in which legal knowledge is easily accessible and non-technical, while the court system is almost useless because of cost and/or inefficiency, for example. Equally, we could conceive of a justice system in which the courts were cheap, quick, and efficient but in which litigation was rare because few, if any, members of the population had knowledge of, or recourse to, law. Of the three components of access to justice, the LK component is least likely to be constrained by considerations of cost or scarcity, provided the labour involved in publishing laws is not onerous. Given the importance of publicity to the rule-of-law ideal - non-publication means the law cannot guide conduct - those labour costs would have to be very high indeed to incline against publication. Access to the court system and access to legal expertise look, by contrast, like options likely to be foreclosed or reduced by scarcity and related considerations. A shortage of lawyers would greatly affect the availability of both, as would a lack of funding (however sourced and however distributed). The latter point reminds us of the near ubiquity of time and money in any attempt to measure the "costs" of access to justice: the time involved is both that of the users and operators of the justice system; the money that of the users and of those that pay the system's operators (which need not be two different classes).

What can be said in favour of this broad conception of access to justice? Its expansive nature ensures that it captures much of what is spoken about when access to justice is discussed. It also reminds us of the notion's relative complexity. ${ }^{15}$ It concerns not just access to institutions (the LF component) but also

(UKDC) [Witham]. In the United States, matters are more complicated. See Lassiter v Department for Social Services, (1981) 452 US 18 [Lassiter]; Turner v Rogers, (2011) 387 SC 142 [Turner].

14 JM Buchanan, The Limits of Liberty (Indianapolis: Liberty Fund, 1975 [reprint 2000]) chs 3, 4 and 7, is a classic statement of the argument that legal systems are public goods. Recouping the full cost of the court service from users (litigants) is a mantra of the British Ministry of Justice: "The MoJ's policy is that fees in HM Courts \& Tribunal Service reflect the full cost of the services provided." "Regulatory Policy Committee Impact Assessment: Court Fees, Cost Recovery," online: <https:/www.gov.uk/government/uploads/system/uploads/attachment_data/file/336513/2014-0327__RPC13-MOJ-1959_2___Court_Fees__CCost_Recovery.pdf; last accessed 14 December 2015). A compelling indictment of this policy is Frederick Wilmot-Smith, "Court Costs," London Review of Books (30 July 2015 ) at 10.

15 Some studies with which my analysis is a good fit: Christine Coumarelos et al, "Legal Australia-Wide Survey: Legal Need in Australia" in Law and Justice Foundation, ed, Access to Justice and Legal Needs (Sydney: Law and Justice Foundation of New South Wales, 2012) 7; Trebilcock et al, supra note 2, parts 1, 2; Genn, supra note 6; Consortium on Legal Services and the Public, Legal Needs and Civil Justice: A Survey of Americans (Chicago: American Bar 
access to expertise (the LE component) and to legal knowledge itself (the LK component), and these are plainly not the same. These three components do not raise exactly the same issues when we consider the relative availability of each; we could also expect to have different levels of access with regard to each. The fact that the LK component has some cost implications blocks the assumption that access to justice is entirely a matter of meeting the cost of legal advice and representation (an assumption often behind the glib recourse in this context to "legal aid" as a synonym for "access to justice"). Understood as a scheme of assisted payment for such advice and representation, legal aid is therefore only one element of our broad conception of access to justice. Is there anything significant in the discourse of access to justice that the broad conception misses?

It might be suggested that the right to a fair trial must be included within any plausible conception of access to justice, but this is a step too far. Although in some forms - Article 6 of the European Convention on Human Rights, for example - this right includes access to legal advice and representation, it mainly concerns how the law is, and ought to be, applied within legal proceedings. ${ }^{16}$ The right to a fair trial thus keeps company with notions of (judicial) impartiality, rationality, and role morality. Access to justice, as its name implies, engages largely, but not exclusively, with matters prior to the adjudication of disputes by courts and related bodies. Separating the two aids clarity, showing that the issues each addresses are, though related, significantly different.

While the right to a fair trial must be distinguished from access to justice, it has been suggested that the right to participate in the law reform process should not. It might therefore be inferred that any conception that fails to include it - as the broad conception does - must be unsatisfactory. ${ }^{17}$ The importance of this right in any democratic society is undeniable. It can be understood as an obvious complement to the most basic democratic right - namely, the entitlement to vote on significant collective decisions. In a society in which democracy is reasonably deeply embedded, this entitlement will have local and national manifestations, while also being supplemented by a range of consultation processes. Thus, citizens of democracies not only have the right to vote in general elections for representatives, but they are also entitled to be consulted about local government planning and school decisions, for example. These opportunities for citizen input are not exactly the same as formal voting processes, but they bespeak a commitment to community involvement in public decision making that is an important feature of genuine participatory democracy, where more is demanded of, and expected by, citizens than simply voting for a representative every few years. ${ }^{18}$ And, just as school boards in many democracies consult about, for example, the proposed rebuilding or extension of a particular school, so too do law reform commissions and the like consult about prospective changes to the law. ${ }^{19}$ Such

Association, 1994) at 8, online: <http://www.americanbar.org/content/dam/aba/migrated/legal-

services/downloads/sclaid/legalneedstudy.authcheckdam.pdf $>$.

16 Convention for the Protection of Human Rights and Fundamental Freedoms, 1950, 213 UNTS 221 [ECHR].

17 See Coumarelos et al, supra note 15 at iii.

18 A classic introduction to these issues is Carole Pateman, Participation and Democratic Theory (Cambridge: Cambridge University Press, 1970).

19 In the United Kingdom, the Law Commission for England and Wales and the Scottish Law Commission do not have a legal duty to consult, although both do. See Law Commissions Act 1965, 1965, c 22; see Law Commission, online: $<$ http://www.lawcom.gov.uk/about/how-we-work/> and Scottish Law Commission, online: <http://www.scotlawcom.gov.uk/about-us/\#whatwedo>. 
consultations are important, but their importance is not a function of some or other understanding of access to justice. Rather, they are a consequence of any attempt to make participatory democracy real within populous and complex contemporary nation-states. Democracy is the animating value here, not access to justice.

With respect to justice, it might be said that this notion is missing from the broad conception of access to justice. The limitation upon our concern highlighted above - our interest is in the "justice" supposedly dispensed by the various systems of civil, family, and criminal justice constitutive of contemporary legal systems - might be criticized as harmful. The harm arises from postponing talk about the genuine nature of justice, this serving either to represent the law as a justice-free zone or to obscure the role that conceptions of justice might play in upholding or undermining the distribution of entitlements found in all existing legal systems. ${ }^{20}$ Yet there are two reasons why those interested in access to justice feel entitled to run the risk of this harm. First, explicitly noting the risk serves to reduce its danger - we can bracket the topic of justice without thereby undermining or denying its significance. Second, having done that, we can point out that the topic of justice and its various components is sufficiently complicated as to merit sustained separate attention.

\section{ACCESS TO JUSTICE: WHY?}

\section{A. Preliminaries}

The "why?" here is a shorthand way of expressing this question: what is the normative standing - I have sometimes also said "value" - of access to justice? By "normative standing" I mean the ways, if any, in which access to justice and its three components might be supported or even required by some or other value or set of values. In saying this, I do not hold that all values are moral and political values but, rather, affirm that all values qua values have some real or apparent normative weight. The values in play could be what we would dub "first-order" values like liberty, equality, autonomy, justice, and the like, or they could be "second-order" values, related to first-order values but either not strictly implied by such values or derivable from a number of such values. Efficiency and utility are plausibly regarded as second-order values, if we accept that neither is good in and of itself, as are notions like fairness and reasonableness, which usually depend for their content upon first order values and various institutionally or conventionally embedded standards and expectations. Hence, what we regard as fairness in the distribution of health care may be quite different to fairness in the playing of particular sports. Secondorder values are intermediate normative notions, occupying the space between first-order values, on the one hand, and their real world application and realization, on the other.

Other notions, which can be labelled value cluster concepts, might also be in play in the exploration of the normative standing of some or other entitlement, institution, arrangement, or practice. ${ }^{21}$ These are

20 Thus, "[ $\mathrm{t}]$ he liberal theory of justice is seen neither as a cause of substantive injustice, nor, surprisingly, even as an important contributor to its rectification." Macdonald, supra note 7 at 292.

21 For an introduction to cluster concepts, see KP Parsons, "Three Concepts of Clusters' (1973) 33 Philosophy \& Phenomenological Research 514; in Parson's terms, value cluster concepts are most similar to "law cluster terms' (at 518-519). See also Berys Gaut, “'Art' as a Cluster Concept” in Noel Carroll, ed, Theories of Art Today (Madison: University of Wisconsin, Press 2000) 25. 
closely related to first- and second-order values in that the realization or implementation of a value cluster concept serves also to realize a number of first- and/or second-order values. "Democracy" and "the rule of law" are obvious candidates for the role of value cluster concepts, since the realization and value of both is not reducible to any single value; rather, both seem to protect and advance multiple other values.

Our task, then, is to determine which values, conceived in this way, might support access to justice. It is tempting to follow current usage and regard this search as one of supporting or grounding a "right" to access to justice, but the term used here is "entitlement." 22 That is because the latter refers to a broader class than the former, including all realizable normative claims and interests. Of all of our realizable normative claims and interests, some might be particularly important and, thus, characterized as rights, as having pre-emptory normative force. But whether or not an entitlement to access to justice belongs within the subclass of rights or "merely" within the broader class of entitlements should, in the absence of prior argument, be an open question. It is regarded as such here, a consequence being that no assumptions are made as to the exact place this entitlement should occupy within our overall scheme of value. Rights talk, by contrast, places all entitlements that are rights at the apex of that scheme, regarding the entitlement in question as being of overriding importance - another's right is something with which no one should interfere (without consent, at least). ${ }^{23}$

Two further points about the entitlement to access to justice must be noted. The first is that this entitlement might be normatively over-determined. It could therefore be supported by, or an entailment of, a number of ostensibly quite different normative arguments. The second point is a reminder. Bear in mind that, although what follows speaks most often in the singular with regard to this entitlement, it is clearly not univocal. That follows from the simple truth that access to justice has three components: the macro-level entitlement to "it" is therefore three separate micro-entitlements, and we must not lose sight of the two possibilities that this presents. One is that the three entitlements may differ in status, not being of equal importance. And the second is that, in examining the normative standing of access to justice, the normative case could differ from one micro-entitlement to another. Nevertheless, I assume from this point on that the best kind of account of the value of access to justice is one that fits its three components in this double sense: it shows the value of each of them and holds that the value of each is the same. I adopt this default position - henceforth labelled "the range assumption" - in the belief that an account of the value of access to justice that takes this form is virtuously general, showing the wholesale value of all three components. Clearly, there is no guarantee that any particular account of the value of access to justice will satisfy the range assumption, nor will failure to satisfy it discredit completely any such account. The range assumption is accompanied in what follows by another, closely related "determinacy assumption." This holds that the best kind of account of the value of access to justice must offer not only arguments that accommodate all of its components; such accounts must also have genuinely compelling (or determinate) normative power.

\footnotetext{
22 Two instances of current usage from very different contexts are: Trebilcock et al, supra note 2 at 1; Francesco Franconi, ed, Access to Justice as a Human Right (Oxford: Oxford University Press, 2007) at 1.

23 A still pertinent examination of the foibles of rights talk and rights infatuation is MA Glendon, Rights Talk (New York: Free Press, 1991).
} 
Finally, there is an objection. The task of examining the normative standing of access to justice could be regarded as academic in the pejorative sense. Since some of the components of access to justice are already embodied in various legal requirements in numerous jurisdictions, the question of the entitlement's normative standing is surely irrelevant. It is already protected and, presumably, this is the result of it being normatively significant. Of these two points, the first seems absolutely undeniable: some aspects of some of the components of access to justice are embodied in various laws and related provisions. However, the level of protection each component (or aspect thereof) receives often differs as between criminal and non-criminal trials; it is also true that there is no common law jurisdiction in which all three components are fully protected. Since the degree to which the entitlement is embedded within and across legal systems is therefore patchy, it is surely not "merely" academic to consider how this situation might be justified. The second point also seems plausible, but it can be accepted only with a caveat. While it appears sensible to presume that entitlements do not become embodied in the law without good (potentially normative) reasons, this presumption must be rebuttable because of what we know about law creation in legislatures and related bodies. What we know is that there are often many more forces at work in that process than the dictates of sound normative reason. Not only are such bodies subject to intense lobbying, but they are also prone to downright blunders. ${ }^{24}$ This mortifying possibility provides a clear rationale for an examination of the normative basis of all areas of statute and like law, not just those bits that deal with access to justice.

\section{B. Access to Justice: Bulwark against Arbitrary Power?}

$[\mathrm{N}]$ on-domination ... represents a control that a person enjoys in relation to their own destiny and such control constitutes one familiar type of power: the power of the agent who can prevent various ills happening to them. ${ }^{25}$

What is arbitrary power? How, if at all, might the denial of access to justice place one in its path? Consider three obvious and not completely hypothetical denials of access to justice. These examples present a test for the argument from non-domination but take hypothetical form so as to avoid jurisdictional specificities. If the argument cannot handle these examples, then it is unlikely to illuminate any actual access-to-justice provisions in existing legal systems. If it can, then we have a general account of what makes denials of access to justice wrong that could be brought to bear upon particular access-to-justice provisions.

1. $\mathrm{M}$ is apprehended by agents of the immigration authority in an airport in a foreign country during his journey home. Instead of allowing $M$ to pass through the airport and board his flight, the authorities detain $\mathrm{M}$, allow him only perfunctory access to a lawyer, and then deport him to a third country. Agents of the immigration authority only attempted to contact M's lawyer a short time before deporting him, having until

24 See Anthony King \& Ivor Crewe, The Blunders of Our Governments (London: Oneworld, 2013) for numerous salutary reminders.

25 Philip Pettit, Republicanism (Oxford: Clarendon Press, 1997) at 69 [Pettit, Republicanism]. 
the time of deportation told M's lawyer and representatives of his government that he would be held in the usual immigration detention facility. Call this the "Arar" scenario. It is an obvious denial of access to justice, specifically of the LK and LE components, insofar as the immigration authority took no genuine steps (1) to convey information to $\mathrm{M}$, or allow $\mathrm{M}$ access to information, about his legal rights and duties in that country or (2) to ensure $M$ had meaningful access to legal advice and representation. $^{26}$

2. N, like many other low paid workers, entered into a contract with a last minute payday loan company - W - and is in debt to the company. Worried by N's default, or the chance of default, $\mathrm{W}$ sent $\mathrm{N}$ and many other customers a letter that purported to be from W's lawyers. The letter reminded $\mathrm{N}$ of the consequences of default, told her that debt recovery proceedings had been, or will be, initiated, and that this process was a costly one; more costly, by far, than repaying the debt. The letter was not from W's lawyers at all but was created by $\mathrm{W}$ in an effort "to maximise ... collections by unfairly increasing pressure on customers." ${ }^{27} \mathrm{~N}$ lives in a society with a reasonably complex legal system in which access to legal advice costs much more than $\mathrm{N}$ can afford. All of the neighbourhood law centres that existed in N's country, which were funded by central and local government, were closed in 2009. Call this the "Wonga" scenario. It is also an obvious denial of the LK and LE components of access to justice.

3. S, sometimes a low-paid bar worker and sometimes dependent upon income support, is a member of a political group that published ostensibly defamatory material about a large multi-national corporation. The corporation is pursuing a libel action against $\mathrm{S}$, claiming damages of $£ 100,000$. S cannot afford legal advice and representation to defend this claim and lives in a jurisdiction that denies legal aid for libel actions. $\mathrm{S}$ represents herself in the legal action but is hampered by the fact that she cannot afford to pay daily charges for transcripts of trail proceedings (£750) nor pay for expert evidence and related trial costs. Although $\mathrm{S}$ has access to the courts in her jurisdiction, it is access of the hollowest kind: she can represent herself but not adequately because of transcript and related costs. This situation - call it the "Steel" scenario - is for that reason alone a clear denial of the LF component of access to

26 See "Report of the Events Relating to Maher Arar: Analysis and Recommendations," online: <http://www.sirccsars.gc.ca/pdfs/cm_arar_rec-eng.pdf $>$; D Cole, "Getting Away with Torture," online:

$<$ http://www.nybooks.com/articles/archives/2010/jan/14/getting-away-with-torture/?pagination=false >.

27 "Voluntary Application for Imposition of Requirement," Doc CC1-IP-039350 (25 June 2014) at para 1.1, online: $<$ https://www.fca.org.uk/your-fca/documents/requirement-notices/wonga-group-limited-vreq $>$. This scenario is based upon the events of which this application was the culmination: Hilary Osborne, "Wonga Should be Investigated by Police over Fake Letters, Law Society Says," The Guardian (27 June 2014), online:

$<$ http://www.theguardian.com/business/2014/jun/27/wonga-fake-letters-police-law-society-blackmail>; Rupert Jones,

"Wonga's Fake Legal Letters Passed to Police," The Guardian (26 June 2014), online:

$<$ http://www.theguardian.com/business/2014/jun/26/wonga-fake-legal-letters-passed-police>. 
justice; it also undermines this component on another ground - namely, by putting legal action for libel beyond the range of all but the wealthy. ${ }^{28}$

Are these three denials of access to justice also instances of subjection to arbitrary power? Philip Pettit, one of the leading contemporary civic republicans, has done much not just to unpack this notion in general terms but also to elucidate the conception of liberty upon which it rests. He calls this conception "liberty (or freedom) as non-domination" and defines non-domination by reference to arbitrary or dominating power, its antonyms: "One agent dominates another if and only if they have a certain power over that other, in particular a power of interference on an arbitrary basis." ${ }^{, 29}$ As to the latter, "[a]n act is perpetrated on an arbitrary basis ... if it is subject just to the arbitrium, the decision or judgement, of the agent; the agent was in a position to choose it or not choose it, at their pleasure." ${ }^{\prime 30}$ Furthermore, when we say this, we imply, because interference with others is involved, that the act in question "is chosen or rejected without reference to the interests, or the opinions, of those affected. The choice is not forced to track what the interests of those others require according to their own judgements. ${ }^{" 31}$ On this view, an act of interference "will be non-arbitrary to the extent that it is forced to track the interests and ideas of the person suffering the interference.",32

Interference, for Pettit, includes both actual interference - in the form of physical coercion, manipulation of choice situations (including the range of options available, their payoffs, and their costs), and control of information - as well as the capacity for interference. Dominating or arbitrary power need not always be utilized in order to exist; the realistic ability to exercise such power is enough. An unexercised capacity to wield arbitrary power does not, unlike our unexercised ability to play piano, undermine the capacity itself. It follows from this that, for Pettit and other contemporary republicans,

28 The scenario derives from Steel and Morris v UK, [2005] 41 EHRR 22 [Steel and Morris].

29 Pettit, Republicanism, supra note 25 at 52 . Pettit has tweaked his account of non-domination, principally in "Keeping Republican Freedom Simple: On a Difference with Quentin Skinner" (2002) 30 Political Theory 339; Philip Pettit, "Free Persons and Free Choices" (2007) 28 History of Political Thought 709; Philip Pettit, "Republican Freedom: Three Axioms, Four Theorems" in Cecile Laborde \& John Maynor, eds, Republicanism and Political Theory (Cambridge: Cambridge University Press, 2008) 102 [Pettit, “Axioms”); Philip Pettit, On the People's Terms (Cambridge: Cambridge University Press, 2012) ch 1, 2 [Pettit, On the People's Terms]; Philip Pettit, Just Freedom: A Moral Compass for a Complex World (New York: Norton 2014) part 1. The changes are mainly of vocabulary and formalization, there being no substantial changes such that they undermine the presentation of Pettit's position offered here. That being so, there is no salient reason to begin with the later as opposed to the earlier statement of his position.

32 Ibid.

Ibid. Pettit, Republicanism, supra note 25 at 55.

Ibid. “Arbitrariness' in Pettit's sense does not exactly match its more usual legal and non-legal senses (see William Lucy, "The Rule of Law and Private Law" in Lisa Austin \& Dennis Klimchuk, eds, Private Law and the Rule of Law (Oxford: Clarendon Press, 2014) part 2, s 2 for four of these), but this is unproblematic, since Pettit's sense highlights something important that existing usage fails to accommodate. Nevertheless, the difference between ordinary senses of arbitrariness and Pettit's sense, alongside some alleged problems with determining interferees' interests (Frank Lovett,

"Republicanism," Stanford Encyclopedia of Philosophy (Stanford, CA: Stanford University Press 2014) at 13, online: $<$ http://plato.stanford.edu/entries/republicanism>) led him subsequently to adopt the term "uncontrolled interference" in its stead. Pettit, On the People's Terms, supra note 29 at 30. 
domination can exist without actual interference..$^{33}$ A dominates, or has arbitrary (or alien) power over, B by virtue of having the ability to brandish that power. For interference to count as such, it must, if actual, make matters worse for the party interfered with or, if a capacity to interfere, be the power to make matters worse. ${ }^{34}$ There is, for Pettit, no absolute baseline against which "worse" and "better" are assessed, there being different baselines in different contexts. ${ }^{35} \mathrm{He}$ is keen to emphasize, though, that these baselines are not necessarily always moral. Key components of the republican conception of freedom, including what interference and arbitrariness look like, are not, he claims, "essentially valueladen" or "moralized." ${ }^{36}$ Neither the range nor intensity of interference need be absolute. Interference, or the capacity to interfere, can exist with regard to only one small area of an agent's conduct (you, for example, can dictate what I must eat for dinner) or whole tracts of conduct (when, for instance, I am your slave) ${ }^{37}$ Interference can differ in intensity insofar as its deployment is more or less easy and its effects are more or less powerful; those effects must, of course, have some power in order to count as interference. $^{38}$

The three key components of domination, therefore, are (1) actual adverse interference or the capacity for such; (2) on an arbitrary basis; and (3) in some or all aspects of the conduct or choices available to others. That is the target against which the republican conception of freedom is aimed. But what, precisely, is wrong with arbitrary power and why should we strive to eradicate it? Although it might seem silly to pose this question, raising it allows us to clarify exactly what republicans value. Moreover, we can do that without unpacking all of the principal themes of the republican political program, including its models of justice, democracy, citizenship, and its conception of the good life. ${ }^{39} \mathrm{~A}$ truncated account of what republicans value can be constructed from two elements of Pettit's thought that might mistakenly be regarded as trivial but that are actually crucial.

One element arises from Pettit's sketch of the reality of living with arbitrary power and with nondomination. A social context in which the flows of information and public knowledge are much like our own, and in which we can know more or less exactly what we currently know about one another's social, personal, and political lives, is one in which the existence of domination and non-domination will be common knowledge. Hence, domination is "generally going to involve the awareness of control on the part of the powerful ... [and] the awareness of vulnerability on the part of the powerless." As a result, "the powerless are not going to be able to look the powerful in the eye, conscious as each will be ... of this asymmetry." ${ }^{40}$ By contrast,

\footnotetext{
33 Pettit, Republicanism, supra note 25 at 63-64; Pettit, Axioms, supra note 29 at 110-111; Pettit, On the People's Terms, supra note 29 at 56-59; Quentin Skinner, "Freedom as the Absence of Arbitrary Power," in Laborde and Maynor, supra note 29, 89; Maurizio Viroli, Republicanism (New York: Hill and Wang, 2002) 10.

34 Pettit, Republicanism, supra note 25 at 52.

35 Ibid at 53 .

36 Ibid at 56; Petitte, Axioms, supra note 29 at 117. See also Pettit, Republicanism, supra note 25 at 54: the notion of interference is "entirely unmoralized."

37 Pettit, Republicanism, supra note 25 at 58.

38 Ibid at 57.

39 Pettit, On the People's Terms, supra note 29, provides an overview of some of these matters.

40 Pettit, Republicanism, supra note 25 at 60-61.
} 
the enjoyment of non-domination in relation to another agent - at least when that agent is a person - goes with being able to look the other in the eye, confident in the shared knowledge that it is not by their leave that you pursue your innocent, non-interfering choices; you pursue those choices as of publicly recognised right. You do not have to live either in fear of that other, then, or in deference to them. The non-interference you enjoy at the hands of others is not enjoyed by their grace and you do not live at their mercy. You are a somebody in relation to them, not a nobody. You are a person in your own legal and social right. ${ }^{41}$

This "eyeball test," which could be taken as little more than a bon mot, actually constitutes a picture of community, a mode of belonging in which all in a polity have the same standing and value: it entails that everyone is a person in their own right. ${ }^{42}$ Contemporary republicans thus value that kind of society and the forms of political community consistent with it.

The second element, which might be regarded as a trite list of pros and cons, is found in Pettit's characterization of non-domination as a personal, instrumental good. Highlighting the virtues of this good is, in large part, a matter of illuminating the vices of subjection to arbitrary power. Pettit notes three such vices and corresponding virtues. In the positive register, the virtues consist of three freedoms. Non-domination promises, first, not just freedom from interference but also

from uncertainty, and from the associated anxiety and inability to plan; [second, freedom] from the need to exercise strategy with the powerful, having to defer to them and anticipate their various moves; and [third, freedom] from the subordination that goes with a common awareness that the person is exposed to the possibility of arbitrary interference by another. ${ }^{43}$

Living one's life in a polity marked by these freedoms is surely better, in multiple respects, than living in one in which uncertainty, deference, and subordination hold sway. One's life in a polity of the former kind can be fulsomely committed to one's goals and, as a result, more authentic, in the sense that one's life plan is truly of one's own making. That, at least, is the way of living on offer under a regime of republican freedom, and it is either foreclosed or under constant threat in a regime of arbitrary power.

With this sketch of republican freedom in mind, we can turn to our three hypotheticals. Are these denials of access to justice also instances of domination - arbitrary interferences with the conduct or choices of others? In the Arar scenario, the interference is both physical and manipulative. M was apprehended and detained by agents of the immigration authority and then held in a secure detention centre. He was subsequently taken to an airport, placed on an aircraft under guard, and delivered to the security services of another state. After that, he was imprisoned and tortured by agents of that state's security and prison services. It is clear that absolutely none of these physical interferences were carried out at M's bidding or with any attention at all to his avowable interests and ideas. Those who

$41 \quad$ Ibid at 71.

42 Pettit, On the People's Terms, supra note 29 at 84.

43 Pettit, Republicanism, supra note 25 at 89. 
apprehended $\mathrm{M}$ and held him did what they wished with him: he was at their mercy, treated by them as if he was a nobody. He was not regarded, and plainly not treated, as a person in his own legal and social right.

That much is also obvious from the way in which the authorities dealt with M's lawyer. In making no effort to inform $\mathrm{M}$ of his legal standing, and no genuine effort to inform his lawyer as to his whereabouts and what they intended to do with him, they announced their lack of interest in M's standing and views. $M$ was already in their physical power, subject to their dominion; providing him with no information and making no genuine effort to contact his legal representative were simply additional manifestations of that dominion. Thwarting communication with M's lawyer was a means of ensuring that M had no information about his choices, closing off all options to him except those that the authorities chose to take. This manipulative interference might seem trivial in comparison to the physical control the authorities exercised over $\mathrm{M}$, but it stands as a significant testament both to their dominion and to their flimsy regard for legality. There can, of course, be no question that both the physical and manipulative inferences with $\mathrm{M}$ made him worse off. At the time he was apprehended, he was a man destined to return home to family and friends in a matter of hours; as a result of the interferences, he was imprisoned and tortured for 374 days, returning home more than one year later than he had hoped.

Unlike Arar, the Wonga scenario is not one in which the potential sources of interference are a matter of physical control. The fake letters, as the regulator noted, were efforts to bring pressure to bear upon debtors, a means of "changing the range of options available [to them], by altering the expected payoffs assigned to those options." ${ }^{44}$ The two most salient options were: (1) continue with the payments as required under the debt agreement or (2) default (or continue to default) and re-structure the debt via a new contract. The letters were attempts to circumvent the latter, principally by altering the pay-offs and costs that this option bore. Under normal circumstances, they would be the costs of entering into a new contract with the lender, with new repayment and interest terms, which would presumably be more beneficial (in terms of period but not in the amount of repayment) to the borrower. The letters purported to increase the costs of this option by claiming that legal action to secure repayment of the debt had begun, or was about to begin, and that this process was itself costly. This threat of imposing extra costs over and beyond those associated with the repayment of the original debt was, of course, the instrument of pressure and clearly counts as interference in Pettit's terms. Was it also an arbitrary interference with the debtors, and did it make matters worse for them?

Taking the second part of the question first, it might be answered in the negative. The thought here is that if the debtors did indeed discharge their debts, either on time or before the commencement of legal action, then that would surely be to their benefit. Of course, the "surely" in this sentence bears much weight. For it might have been the case that some of those people who received fake letters were willing and able to discharge the debt at the time of receipt. But it is also likely - perhaps even more likely that many recipients of these letters were unable do so. Their circumstances, after all, were such that they had entered into contracts with a lender that, on any general market measure, were extremely disadvantageous, the reason for doing so presumably being a combination of serious financial need and the unavailability of other sources of credit.

$44 \quad$ Ibid at 53. 
This response also serves as a reply to the first part of the question. If we assume that many recipients of the fake letters were unable to repay their debts at the time of receipt, then it is difficult to show that the interference the letters represented was in the interest of those debtors. This appearance of arbitrariness - of being a product of the lender's whim or dominion and of their disregard for their debtors' interests - is further reinforced by the deception deployed, for if there were good legal grounds for sending the letters, then why were they sent in the names of fake law firms? In a context in which legal knowledge and advice is (in all senses) easily available, a deceptive ruse like this would be pointless - a visit to one's neighbourhood law centre would quickly resolve the issue. The fact that, on our version of the Wonga scenario, no such access to legal knowledge and advice existed, adds to the power of the interference and reminds us that one way in which domination can be countered is via social and constitutional arrangements that ensure "reciprocal power." "resources of dominator and dominated more equal so that, ideally, a previously dominated person can come to defend themselves against any interference on the part of the dominator." ${ }^{46}$ Some of the relevant resources in this instance would be legal knowledge and advice.

This point highlights another potential source of, or aid to, interference and domination, namely the closure of legal advice centres in N's jurisdiction. Does local and central government withdrawal of financial support for those centres constitute an interference with $\mathrm{N}$ that worsens her situation? And, if so, is that interference arbitrary? The move from a situation in which legal advice is freely and easily available to $\mathrm{N}$ to one in which it is available only to those who can pay is surely a worsening of N's situation if she cannot afford legal advice. This could only be denied if it were true that having access to legal knowledge and expertise was in some general sense harmful for $\mathrm{N}$ or those in N's position. That is surely never the case, even when the law stands against one. For, although the legal consequences one faces in that situation are adverse, is it not better to know that than to remain in ignorance? The latter is bliss only when harm never follows.

This worsening of N's situation is also an interference since it forecloses an option previously available to N. Its arbitrariness depends upon the basis of the decision. Since this decision constitutes a potential interference by government with citizen - an exercise of imperium rather than dominium - the test is slightly different from that required when the interference is by citizen on citizen ${ }^{47}$ In the latter case, the decision and interference it warrants has to match up with the avowable interests of the interferee. In the former case, the decision and interference must match up with the common avowable interests of the citizenry as a whole. Of course, there might be an overlap here: if it could be shown that the closure of legal advice centres was undoubtedly a necessary result of a policy of financial austerity, itself assuredly required for the economic well-being of N's society, then it could be argued that the decision was in N's avowable interests and in her and all other citizens' common avowable interests. An

45 The real Wonga scandal unfolded in the United Kingdom when there was (as there still is) some degree of free or low cost access to legal advice. For the current situation, see Mayo et al, supra note 7 at chs $4-9$. The deception was not, however, discovered by lawyers advising recipients of fake letters, but by the Financial Conduct Authority and its predecessor, the Office of Fair Trading. See Rupert Jones, "Wonga to Pay £2.6m Compensation for Fake Debt Firm Letters," The Guardian (25 June 2014), online: <http://www.theguardian.com/money/2014/jun/25/wonga-compensationbill-unfair-misleading-practices $>$.

46 Pettit, Republicanism, supra note 25 at 67.

47 Ibid at 13. 
interference that is required to, and does indeed, track the interests of those affected by it in either of these two ways is not arbitrary. ${ }^{48}$ A decision formulated and implemented without regard to the interests of those whom it adversely affects is halfway to being arbitrary. The remaining half of the journey requires that the decision be subject only to the judgment of the maker, being entirely within his or her dominion.

There are also two apparent sources of interference in the Steel scenario. My use of the word "apparent" is deliberate, a means of highlighting two supposed oddities about each source. One source was the initiation and pursuit of legal action, and some might find it odd to regard the prosecution of a prima facie valid legal claim as interference. Yet, as Pettit makes clear, and as is perhaps only a little less obvious from our discussion of Wonga, where the lender was legally entitled to remind debtors of their obligations, conduct does not cease to count as interference because it is morally (and possibly legally) legitimate. ${ }^{49}$ If the fake letters in Wonga amounted to arbitrary interference, then must the initiation and pursuit of legal action also count as such? Not necessarily. For, although (1) the threat of legal action is undoubtedly a means of both closing down some options previously available to the interferee and changing the pay-offs associated with others and (2) is available at the whim of a sufficiently wealthy interferor, it can be countered by the easy availability of expert legal advice to the interferee. ${ }^{50}$ The same is true of the actual pursuit of legal action, which, unlike the "mere" threat of it, is in most familiar legal systems backed up by the coercive power of the justice system to compel attendance at court, punish contempt, and so on. Resources of would-be dominator and dominatee are thereby brought closer to equality, achieving what the European Court of Human Rights calls "equality of arms" both before and during a trial. ${ }^{51}$ There is no such equality of arms in the Steel scenario nor was there in the actual case. Not only did $\mathrm{S}$ have to represent herself in court and rely upon lawyers acting pro bono, while the multinational corporation had several senior and junior lawyers available, she was also hampered by being unable to meet the costs for transcripts of proceedings and other matters.

48 Ibid at 55-56. The ideas of avowable interests of the interferee and the common avowable interests of the citizenry arise from Philip Pettit's “The Determinacy of Republican Policy: A Reply to McMahon" (2006) 34 Philosophy \& Public Affairs 275 at 278-280; see also Christopher McMahon, "The Indeterminacy of Republican Policy" (2005) 33 Philosophy \& Public Affairs 67; and Christopher McMahon, "Nondomination and Normativity" (2007) 88 Pacific Philosophical Q 319. Pettit's “tough luck test" governs the legitimacy of this political decision. Pettit, On the People's Terms, supra note 29 at $177-179$.

49 Pettit, Republicanism, supra note 25 at 54.

50 Although there are professional ethical constraints upon lawyers when advising clients about the efficacy of legal action, it seems that sufficiently wealthy clients can insist on pursuing action regardless. See Simon Godley, "Judge Attacks Mike Ashley for Abusing Legal System Against Rangers Boss," The Guardian (22 January 2016), online: $<$ http://www.theguardian.com/business/2016/jan/22/judge-attacks-mike-ashley-for-abusing-legal-system-againstrangers-boss $>$.

51 Steel and Morris, supra note 28, para 59 (para 69 notes the obvious disparity in level of legal expertise and help as between the parties in the actual case: "[I]t could not have failed, in this exceptionally demanding case, to have given rise to unfairness"). See also ECtHR, De Haes and Gijsels v Belgium, Appl no 19983/92 (24 February 1997); ECtHR, Case of Bulut v Austria, Appl no 17358/90 (22 February 1996). 
The second potential source of interference in the Steel scenario is that of the abolition of legal aid for defamation, and it need not detain us long. ${ }^{52}$ Can a political decision such as this, enacted by the government of the day, be an instance of arbitrary interference? The issue here is exactly the same as that in play in the withdrawal of financial support for legal advice centres in the Wonga scenario. If the decision to abolish legal aid for defamation actions adhered to the same constraints - it was required to, and did indeed, track the common avowable interests of the citizenry affected by it - then it will not be arbitrary.

Pettit's picture of arbitrary power and non-domination seemingly makes good normative sense of our token denials of access to justice. It throws light on what is wrong in these cases. However, it cannot tell us what is wrong with every denial of access to justice, since not all such denials are necessarily instances of domination - arbitrary interferences in the conduct or choices of another. As just noted, a political decision to stop legal aid for certain proceedings, leaving nothing in its place but the possibility of conditional fee agreements, could in some circumstances represent both the avowed interests of prospective litigants and those of all other members of the polity. If it did, it would not be arbitrary in the republican sense. However, many denials of access to justice - making legal information hard to obtain, preventing access to legal advice and representation, imposing very high court and related costs - are straightforward exercises of arbitrary power. Is that worth knowing? Some may doubt it.

One reason for doubt is that the alleged wrong of being subject to domination is either insufficiently serious to count as a genuine harm or too expansive to be helpful, dubbing most instances of influence instances of domination. In doubting the seriousness of the alleged wrong, the first limb of this complaint questions the harm that the threat, or the actual initiation, of legal action represents. At least, that is the way in which it is interpreted here for, although it could be taken as an objection to the republican conception of domination, I regard that as the crux of the second limb of this complaint. Proponents of the first limb must, then, regard legal action or its threat as being so untroubling as to be unable to count as domination. Those who have feared legal action more than death and taxes are therefore in the grip of a mistake. ${ }^{53}$

Numerous considerations suggest that there is no mistake. There is sound empirical evidence to show that those with legal problems find them to be a major source of anxiety and stress. ${ }^{54}$ The sheer volume of this research makes it difficult to dismiss the point that many of those involved in legal action find it, at the very least, significantly troublesome. These findings also remind us that the view that legal action is, in general, a bad thing for those on the receiving end, is institutionally embedded in many legal systems. ${ }^{55}$ All the common law jurisdictions have torts of abuse of process and malicious prosecution, and many legal systems also have related constraints upon frivolous and vexatious litigation.

52 This was done, in England and Wales, by the Access to Justice Act 1999, 1999, c 22, s 6(6), Schedule 2. Legal action for defamation can now only be funded by one's own money or via conditional fee agreements with lawyers.

53 Judge Learned Hand was one such timorous soul. Ronald Dworkin, Law's Empire (London: Fontana, 1986$)$ at 1.

54 See, eg, Ab Currie, "The Legal Problems of Everyday Life" (2009) 12 Sociology of Crime, Law \& Deviance 1 at 9: "Overall, 58.9\% of respondents said that the problem had made their day-to-day lives somewhat to extremely difficult and $86.7 \%$ said that resolving the problem was somewhat to extremely important."

55 It may well be a bad thing for initiators, too, but the fact that initiation lies entirely in their power prevents any suggestion that they are victims of arbitrariness at that stage. 
These torts differ in both their history and requirements, but part of the rationale for both must be that there is a wrong that they aim to prevent and for which they must compensate. And, for there to be a wrong, there must usually or generally be harm to someone; most obviously here, to the party on the receiving end, the one being dragged, or being threatened with being dragged, through the courts. There might be other more general or systemic wrongs in play - a worry about clogging the courts with unmeritorious cases being one of them - but it is inconceivable that such torts would exist without an agent-specific harm also being present. That is because all torts have victims in the specific sense of one who has suffered as a result of the conduct of another; whatever else they are, torts are overwhelmingly bilateral wrongs. ${ }^{56}$ This rationale for these torts - or an element of it - also presumably informs the prohibitions in many countries, either in statutory or other form, upon particular agents deemed to be vexatious litigants. The very description of the conduct here tells us a good deal about the wrong: the victims of these litigants are vexed, harassed, subject to "terrorism."

These considerations show that being on the receiving end of legal action is a bad thing, a worsening of one's situation. Our discussion of the Wonga and Steel scenarios shows that the threat or pursuit of legal action can also constitute an interference. It is therefore the case that bringing or threatening legal action can count, in republican terms, as domination, provided that decision is entirely within the power of the initiator. What, then, of the second limb of the objection under consideration: is the republican notion of domination too expansive? If every instance of influence is also an instance of domination, then the latter category surely becomes useless because it includes too much.

However, domination, for Pettit, has features that ordinary run-of-the-mill influence lacks. It is no exaggeration to say that my nearest and dearest have a good deal of influence over me: weekend activities and meal options are often decided after consultation and discussion of their desires and needs as well as their views of my desires and needs. Changing my choices and plans in light of their views certainly shows that I am subject to their influence, yet, as we know, I am only dominated by them if at least two conditions are satisfied. First, they must have actual or potential power over me that I lack over them and, second, that power must marry with a lack of any duty on their part to consider my avowed interests. This double-edged asymmetry goes to the core of domination, and it is absent in ordinary cases of influence. Thus, the influence my family has over me is like the influence my doctor or life coach wields -- their judgments are good faith attempts to identify and track my own interests. Although the warrant for these judgments - familiarity in the one case, expertise in the other - is different, both aim to highlight features about my condition that I either misunderstand or do not know.

Even if domination can be distinguished from influence, it might still be maintained that the former is too inclusive a notion to be helpful. One reason for thinking so is that, on Pettit's account, domination

56 This is a non-controversial point about private law in general, although some think it is denied by some lawyer economists. A sophisticated unpacking of the point is Ernest Weinrib, The Idea of Private Law, revised ed (Oxford: Clarendon Press, 2012). There are numerous "tri-lateral' torts (inducing breach of contract and causing loss by unlawful means are two).

57 The hyperbolic term is reported in Michael Taggart, "Alexander Chaffers and the Genesis of the Vexatious Actions Act 1896" (2004) 63 Cambridge LJ 656 at 659. For the current English law, see the Senior Courts Act 1981, 1981, c 54, s 42 (originally the Supreme Court Act 1981), which allows the issue of various civil restraint orders against vexatious litigants. See also HM Courts and Tribunals Service, “Guidance: Vexatious Litigants”(15 December 2014; last updated 8 May 2017), online: <https://www.gov.uk/guidance/vexatious-litigants> for a list of such litigants in England and Wales. 
can exist within the sphere of that which is morally and legally permissible. That is true, but should it be thought problematic? It might seem so were we to equate domination with illegitimacy of some kind or other, yet Pettit rejects this equation. He does so because arbitrariness is not, for him, a moralized notion. While this and related claims about non-arbitrariness and domination have been challenged, they are not clearly mistaken. ${ }^{58}$ Nor does the fact that there are numerous accounts of domination available, at least one of which might be moralized, undermine Pettit's position. ${ }^{59}$ At least, it cannot do so until such time as either Pettit's non-moralized account is shown to collapse into that account or that account is proved obviously superior to Pettit's.

Furthermore, this broad issue obscures a question that the objection under consideration must face, regardless of the connection between normative and non-normative accounts of domination. It is this: why should we reject an account of domination that accepts the possibility of domination within the sphere of the morally and legally permissible? Why regard such an account as being too general or too inclusive? The fact that an account of domination allows such a possibility can, on the contrary, be considered an advantage. It could illuminate a puzzling feature of legally and morally permissible activity in capitalist societies - namely, its tendency to entrench or exacerbate existing inequalities. ${ }^{60}$ Those inequalities - of income and opportunity, of health, and of overall quality of life - are not often the direct result of moral or legal wrongs perpetrated by some members of the population upon others. Indeed, those inequalities obtain and persist in the face of practices, institutions, and conduct that are ostensibly legally and morally permissible. Many in contemporary Western societies do legitimate work, pay their taxes, and feed and nurture their children, but they are impoverished and, it seems, their children will be impoverished into adulthood as well. ${ }^{61}$ How is this possible in a context in which these people are at no point the victims of moral and legal wrongs? Pettit's account of domination provides an answer that redounds to its credit.

The argument from non-domination, then, provides a plausible explanation of the wrong involved in some denials of access to justice. As a result, it can also support an entitlement to access to justice as a means of avoiding that wrong, the entitlement standing as a bulwark against instances of manipulation, deception, and threats to unleash (or actual exercises of) power that constitutes domination. These points hold regardless of some of the philosophical objections aimed at contemporary republicanism - that it misrepresents the liberal tradition, for example, or that its conception of freedom is not ultimately distinguishable from negative liberty ${ }^{62}$ - because the non-domination argument is powerful regardless of

58 See the exchange in note 36 above.

59 I have in mind the substantive arbitrary power conception discussed in Frank Lovett, A General Theory of Domination and Justice (Oxford: Clarendon Press, 2010) at 112-119; see also ch 3 and 4 for an overview of different conceivable accounts of domination.

60 For overviews, see AB Atkinson, Inequality (Cambridge, MA: Harvard University Press, 2015) part 1; Thomas Piketty, Capital in the Twenty-First Century (Cambridge, MA: Harvard University Press, 2014). An excellent intellectual history of equality and its travails is Pierre Rosanvallon, The Society of Equals (Cambridge, MA: Harvard University Press, 2013).

61 Samuel Bowles, Herbert Gintis \& Melissa Osborne Groves, eds, Unequal Chances: Family Background and Economic Success (Princeton, NJ: Princeton University Press 2005) provides an introduction to the issue.

62 Charles Larmore holds, contrary to what he takes to be Pettit's view, that "the liberal tradition is not all of a piece." Charles Larmore, "A Critique of Phillip Pettit's Republicanism" (2001) 11 Philosophical Issues 229 at 235-237, while the essays by Ian Carter and Matthew Kramer in Laborde and Maynor, supra note 29, deny that republican freedom 
its true intellectual lineage. It is valid whether derived from a republican or a liberal background framework. I have presented it here as part of the former because I believe, alongside Pettit and other contemporary republicans, that the republican framework is genuinely distinguishable from liberal frameworks. I cannot show that here, nor does anything in the argument turn upon it.

Finally, note that the non-domination argument is contingent, holding only for legal systems as they currently exist in the common law world - complex systems with limited regimes of access to justice. Things could change. Were they to do so in some ways, then the argument would lose its power. It is conceivable, although practically and politically unlikely, that legal advice in these systems might come to be provided on the model of free on-demand, need-based health care. If that happened, then the space for domination would be reduced: Arar and Wonga-type scenarios would be impossible. Free ondemand, need-based legal advice supplemented with similarly available legal representation would reduce the space for domination further, since Steel-type scenarios would not arise. And free ondemand, need-based legal advice and representation, combined with easily available legal information and free access to courts and tribunals, would shrink the space for domination in the legal context to zero. $^{63}$

\section{Range and Determinacy}

This subsection reinforces the argument from non-domination indirectly by examining two arguments - from the rule of law and from equality - often adduced in favour of an entitlement to access to justice. ${ }^{64}$ I show that these arguments cannot satisfy the range and determinacy assumptions, sketched earlier in section II.A. This is a problem, since those assumptions set plausibility conditions that good arguments in support of an entitlement of access to justice must satisfy. The argument from nondomination clearly satisfies those conditions.

\section{Range}

The range assumption holds that a good account of the value of access to justice accommodates all of its components and regards them as equally valuable. If we keep contemporary common law legal systems in mind, then it seems certain that the argument from non-domination must accord equal importance to each component of access to justice. These legal systems are complex, have patchy access to advice and representation, and charge "users" fees for access to courts and impose related costs. For the financially hard pressed - but by no means only those ${ }^{65}$ - these systems are a rich source of potential domination. They can be used as a means of domination by any agent able to incur the costs involved, subject only to the professional ethical constraints binding their legal advisers and the restrictions upon

differs from liberal freedom (see also the essays by Philip Pettit and Quentin Skinner in the same volume and Matthew

Kramer, The Quality of Freedom (Oxford: Clarendon Press, 2003) ch 2).

63 Domination can arise outwith the legal context. Pettit, On the People's Terms, supra note 29, chs 3-5; Philip Pettit, "Law and Liberty" in Samantha Besson and JL Marti, eds, Legal Republicanism (Oxford: Clarendon Press, 2009 ) 39 at 53-58.

64 Contemporary republicanism has its own accounts of equality and the rule of law. See Christian List, "Republican Freedom and the Rule of Law" (2006) 5 Politics, Philosophy \& Economics 201; Pettit, On the People's Terms, supra note 29, ch 2) but neither, so far as I know, has ever been invoked to support an entitlement to access to justice. The actual equality and rule of law arguments used to that end are of a different character, as we will see.

65 See Trebilcock et al, supra note 2. 
vexatious litigation. If such agents wish to use the legal system to "grind others into dust," then it seems they can. ${ }^{66}$ In this context, it would be implausible for the non-domination argument to distinguish between different components of access to justice: each is equally important.

We might think that this judgment would change if, for example, it were possible to improve access to one, but not all, components. Were that possible, then one who valued access to justice would, other things being equal, choose to do that. That choice is not, however, a decision to value one component above others; it is a judgment that improvements in access to justice, wherever they can be made, are valuable. Our judgment about the equal importance of the three components would be challenged only if we were forced to make a choice between improving one and degrading others. It would not be unreasonable for one committed to access to justice to refuse to make such a choice here and now. If the context were different - one, for instance, in which there were no impediments to accessing legal knowledge and advice, legal representation, and courts and tribunals - then a choice might be made. Departures from "gold-standard" access to justice might be acceptable in some circumstances, even to defenders of that entitlement. Much would depend upon what might be gained and lost by such a choice. Recourse to the rule of law as a means of supporting access to justice or one or other of its components is routine. Such recourse, however, is rarely an instance of "argument," the rule of law almost never being shown to generate explicit grounds for access to justice. Rather, it is usually simply assumed that an entitlement to access to justice is required by the rule of law, presumably in the form of something like a direct entailment. ${ }^{67}$ However, as we will see, no such direct and unproblematic entailment exists.

The first problem that besets those attempting to establish such a link is that, while there are not quite as many conceptions of the rule of law as there are jurists, there are still numerous conceptions to choose from. ${ }^{68}$ These conceptions can be placed on a spectrum ranging from thin to thick, the former being

${ }^{66}$ See the remark of Justice Peter Smith reported in Simon Godley, "Judge Criticises Sports Direct in Rangers Legal Case," The Guardian (19 January 2016), online: $<$ http://www.theguardian.com/business/2016/jan/19/judge-criticises-sportsdirect-in-rangers-legal-case>.

67 A few examples: Hryniak v Mauldin, [2014] 1 SCR 87, para 26 (per Karakatsanis J) [Hryniak] (cited with approval by Chief Justice McLachlin in Trial Lawyers, supra note 13 at para 38): "[W]ithout an accessible public forum for the adjudication of disputes, the rule of law is threatened and the development of the common law undermined"; Lord Neuberger, "Justice in an Age of Austerity" (Tom Sargant Memorial Lecture, 2013) at 9, online:

$<$ https://www.supremecourt.uk/docs/speech-131015.pdf $>$ : "The rule of law requires that any persons with a bona fide reasonable legal claim must have an effective means of having that claim considered, and, if it is justified, being satisfied, and that any persons facing a claim must have an effective means of defending themselves"; Kevin Lindgren, AM, QC, "The Rule of Law and Some Aspects of the Current Legal Scene in Australia" (University of Sydney Law School Distinguished Speakers Program, 18 July 2013), online: <http://www.academyoflaw.org.au/publication?id=2>: "The Rule of Law and a strong independent judiciary are empty ideals if people cannot access the courts"; Law Society, "Policy Campaigns: Access to Justice and Rule of Law," online: <http://www.lawsociety.org.uk/policycampaigns/articles/access-to-justice-and-the-rule-of-law/>: "The rule of law underpins the very foundations of access to justice"; Curran \& Noone, supra note 7 at 84-85: "If people cannot access legal help and assistance to seek remedies or enforce their rights, then their participation in society is diminished and the rule of law undermined."

68 A list of all plausible conceptions of the rule of law ideal would be very long. The principal recent sources that must feature on any such list are. Fuller, supra note 9; FA Hayek, The Constitution of Liberty (London: Routledge, Kegan and Paul, 1960) part 2; FA Hayek, Law, Legislation and Liberty (London: Routledge, Kegan and Paul, 1973) vol 1; HLA Hart, The Concept of Law, revised ed (Oxford: Clarendon Press, 1994) at 206-207; HLA Hart, Essays in Jurisprudence and Philosophy (Oxford: Clarendon Press, 1983) ch 3; Joseph Raz, The Authority of Law, 2d ed (Oxford: Clarendon 
more, and the latter less, parsimonious in the number of desiderata they include as constituting the rule of law. Since space does not allow for an examination of all actual and conceivable entries on this spectrum and their relationship with access to justice, how might we proceed? I propose two manoeuvres: first, an examination of what it is that all conceptions of the rule of law - thick and thin have in common and, second, an elucidation of the general difficulty that all thick conceptions present.

The first manoeuvre might be regarded as folly, for what, if anything, could the great variety of conceptions of the rule of law have in common? My answer is: Lon Fuller's eight desiderata, their guiding rationale and constitutive values. ${ }^{69}$ Fuller's desiderata amount to the concept of the rule of law, the argumentative plateau upon which arise all competing conceptions of the rule of law. In an arresting metaphor, what guarantees that the latter are indeed competing views about the same thing is that they "by and large agree about the most general and abstract [rule of law] propositions, ... which form the trunk of ... [a] tree, but they disagree about more concrete refinements or subinterpretations of these abstract propositions, about the branches of the tree. ${ }^{, 70}$ Fuller's desiderata are the trunk of the tree, the concept of the rule of law to which all competing conceptions are connected or relate. ${ }^{71}$ That being so, what do those desiderata tell us about access to justice?

There are eight desiderata: generality (there must be rules), promulgation, non-retroactivity, clarity, consistency (the law being free of contradictions), possibility (the law-setting standards with which human beings can comply), stability (or constancy of law over time), and congruence between declared law and official conduct. Of these, the two most obviously connected to access to justice are the first and second. That a legal system, to comply with the rule of law, must have general rules of some kind, and that those rules must be promulgated, surely implies that addressees of a legal system can know the demands that this system makes upon them and, if those demands are complex, be able to obtain guidance about them. The combination of these two desiderata therefore seems to directly entail the LK and LE components of access to justice. If the law were practically unknowable, in the sense that it was understood only by a taciturn and reticent genius, then both LK and LE components would be thwarted, as would either or both of the generality and promulgation desiderata. The fact that law has supposedly been created, but communicated only to the genius, cannot amount to promulgation in any but a Pickwickian sense, where communication to one other being counts as promulgation. And since promulgation is in doubt, addressees of this putative legal system must also be in doubt as to whether or not there are indeed any general laws or rules applicable to them: they simply cannot be sure until such time as the reticent and taciturn genius speaks (if he ever does).

Are any of Fuller's other desiderata salient with regard to access to justice? It could be suggested that, since all but one of the remaining six are matters of degree, capable of realization to a greater or lesser extent, they should or must be testable in the courts. This connection, if plausible, provides a

Press, 2009) ch 11; NE Simmonds, Law as a Moral Idea (Oxford: Clarendon Press, 2007); Jeremy Waldron, "The Concept and the Rule of Law' (2008) 43 Georgia L Rev 1.

69 See Fuller, supra note 9, ch 2, for the desiderata; they are in service of the "enterprise of subjecting human conduct to the governance of rules" (at 74, 106, 162), the values informing that enterprise being "dignity," responsibility, and, presumably, autonomy (at 162-167).

70 Dworkin, supra note 53 at 70.

71 This claim looks like a hostage to fortune, but how could an alleged account of the rule of law eschew Fuller's desiderata and remain an account of the rule of law? 
normative prop for the LF component. However, the implausibility of this suggestion derives not just from Fuller's view that courts are not a necessary element of the enterprise of subjecting human conduct to the governance of rules and, hence, not a necessary element of the rule of law. ${ }^{72}$ It also results from the suddenness of the move between "matters of degree," on the one hand, and "must be testable in courts (or like institutional forms)," on the other. That the latter simply does not follow, in anything like a direct way, from the former is obvious; equally obvious is that the process of derivation must be reasonably long and complex since we have many similarly aspirational standards that are rightly not testable in courts.

If our concept of the rule of law cannot support all components of access to justice, surely thicker conceptions will fare better? Joseph Raz's account is one such, including not just Fuller's eight desiderata but also at least an additional three requirements. One of these is that "[t]he courts should be easily accessible., ${ }^{, 73}$ Access to justice - or one component of it - is thus built in to this conception of the rule of law. This close connection, alongside the fact that the generality and promulgation desiderata of the concept of the rule of law require the LK and LE components of access to justice, might explain what we earlier took to be a baleful lacuna - namely, the glib invocation of the rule of law as an assumed support for access to justice. Since the connections between the two ideas are so close, glibness is excusable.

In Raz's case, the addition of easy access to the courts as a desideratum of the rule of law is questionable. The reason is that the grounds for this addition, as well as some of the others he adds to the original eight, are not well specified. The addition therefore looks ad hoc. As a general matter, the desiderata of any conception of the rule of law must be justified or explained in the same way as one would explain the desiderata of the concept of the rule of law: by reference to its point and the value(s) it realizes. All eight of Fuller's desiderata flow from the animating idea of the concept of the rule of law the enterprise of subjecting human conduct to the governance of rules - and the values that this idea upholds or protects: dignity and autonomy. However, it is unclear how Raz's access to the courts desideratum flows from this enterprise and those values. We noted that Fuller did not regard courts as a necessary condition for engaging in the enterprise of subjecting human conduct to the governance of rules, and he was surely right about that. ${ }^{74}$ Societies are conceivable that are able to realize this enterprise without the need for courts to adjudicate disputes about the rules by which they are governed. Disputes may not arise because, for example, members of society are angelic and non-disputatious or, more likely, disputes do arise, but members find other ways of resolving them. There is no reason to think that the menu of dispute resolution options is particularly short.

This point might be thought misguided because, by ascribing Fuller's view of the point of the rule of law to Raz, it cannot undermine Raz's case. For Raz's view of the point of the rule of law is quite

Fuller supra note 9 at 55-56.

73 Raz, supra note 68 at 217. I hold that Raz's conception has eleven desiderata because, although he mentions only eight principles (at 214-219), the first contains three, and the third four, sub-principles, two of the latter not overlapping with those in the first principle. Raz's first, second, third, and eighth principles overlap considerably with Fuller's eight desiderata.

74 For an attempt to extend Fuller's first and second desiderata into a broader "publicity condition" that is assumed to include the LF component, see Dyzenhaus, supra note 5 at 480-482; Simon Roberts, Order and Dispute, 2d ed (Louisiana: Quid Pro Quo, 2013) is an excellent reminder of the variety of dispute resolution processes available. 
different to Fuller's. The problem is that it is not. While not exactly identical to Fuller's view - Raz holds that "the basic intuition from which ... the rule of law derives ... [is that] law must be capable of guiding the behaviour of its subjects" ${ }^{\text {"75 }}$ - it is sufficiently close as to make no difference for the present purpose. If the LF component cannot be quickly and easily derived from the enterprise of subjecting human conduct to rules, then it seems very unlikely that it can be quickly and easily derived from the enterprise of guiding human behaviour. How, then, might Raz show that his access to the courts desideratum genuinely follows from, or is part of, the rule-of-law idea? There are two possibilities.

The first holds that this desideratum flows not from the basic idea of the rule of law but, rather, from "the particular circumstances of different societies." importance" on many of the principles of the rule of law, one of which is the access to the courts desideratum. ${ }^{77}$ However, this is an unpromising move. For, if this desideratum does not flow from the basic idea of the rule of law, then the fact that it might be justified by reference to, or derived from, other "circumstances" matters not. Unless those circumstances are either merely surrogates for the rule of law or so tightly connected to it as to be entailments, then the connection with the former is, at best, tenuous. This is even more evident once one considers what it might be for particular circumstances to be "surrogates" for the rule of law or for them to be entailed by the rule of law. Of course, the particular circumstances of different societies might make the rule of law idea more or less salient: more so in contemporary societies, less so in a society of angels. But this obvious truth does nothing, of itself, to show that this idea includes the LF component or that the latter follows from it. Whether or not the latter is required by Raz's conception of the rule of law remains an open question.

However, there is a second possibility that might also answer this question. It holds that the access to the courts desideratum derives not from the enterprise and values that animate the concept of the rule of law but, rather, from additional values that inform Raz's eleven-desiderata conception of the rule of law. What might these be? There is only one candidate. In addition to invoking notions of autonomy and dignity that are almost identical to those utilized by Fuller, Raz invokes the idea of individual freedom. ${ }^{78}$ Regarding the protection of individual freedom as a virtue of the rule of law, says Raz, "is right in the sense of freedom in which it is identified with an effective ability to choose between as many options as possible. Predictability in one's environment does increase one's power of action[]." ${ }^{, 79}$ Since the rule of law is one means of ensuring a reasonable degree of such predictability, then " $[t]$ he rule of law may be yet another way of protecting personal freedom. ${ }^{\prime 80}$ Does the rule of law's protection of freedom support either Raz's access to the courts desideratum or, what amounts to the same thing, the LF component of access to justice?

It might, given the kind of circumstances outlined in the Arar, Wonga, and Steel scenarios earlier in this article. Protection against non-domination might also often be the protection of a sphere of individual freedom, which does not sound the least bit surprising. Yet the question that must be

Raz, supra note 68 at 214.

Ibid.

Ibid.

Ibid at 221-222; for Fuller, see supra note 9.

Ibid at 220.

80 Ibid. 
answered is this: What bears the normative weight here, Raz's conception of the rule of law, or the value that it serves? If it is the latter that really anchors the access to the courts desiderata - and that is how things look - then recourse to the rule of law idea simply gets in the way. It seems "cleaner" and more direct to argue from the value in question to this particular component of access to justice. The rule-of-law idea is a redundant intermediary step in this argument.

This issue is a specific manifestation of a more general difficulty that thick conceptions of the rule of law display in this and related contexts. There is an ever-present risk with such conceptions that the various additional desiderata they include in the rule-of-law idea either (1) are not in fact derivable from the core idea of the rule of law or from its underpinning values or (2) derive exclusively from the latter and not the former. The previous paragraphs have shown that this risk is clearly evident in Raz's account and, that being so, that his conception of the rule of law cannot support each component of access to justice. We also noted that the concept of the rule of law, as articulated by Fuller, is similarly limited. These arguments do not show that all conceptions of the rule of law fail to satisfy the range assumption, but they do show that the best account of the concept of the rule of law, and a leading conception of the rule of law, fail to satisfy it. These failures bode ill for other arguments from the rule of law.

\section{Determinacy}

The determinacy assumption holds that the best kind of account of the value of access to justice must have a genuinely compelling normative power. The argument from equality cannot satisfy this condition, while the argument from non-domination can. What is the argument from equality? There are potentially many such arguments available, the last twenty or so years having witnessed an explosion of work on equality by legal and political philosophers. ${ }^{81}$ In the access to justice context, however, philosophical accounts of equality lurk in the background. The primary focus of equality arguments here is that array of equality and non-discrimination provisions found throughout the common law jurisdictions in various charters, constitutional documents, and treaties. ${ }^{82}$ Insofar as these provisions guarantee equal protection of the laws, or equality before and under the law, then they immediately make problematic a situation in which those with funds can obtain access to justice and those without cannot. If this situation is not one in which equal protection of the laws is denied, or in which the parties do not stand equal before or under the law, then what might such a situation look like? This question,

81 Eg, Elizabeth Anderson, "What Is the Point of Equality?" (1999) 109 Ethics 287; GA Cohen, On the Currency of Egalitarian Justice (Princeton, NJ: Princeton University Press, 2011) part 1; GA Cohen, If You're An Egalitarian, How Come You're So Rich? (Cambridge, MA: Harvard University Press, 2000) ch 6, 8, 9, 10; GA Cohen, Why Not Socialism? (Princeton, NJ: Princeton University Press, 2009); Ronald Dworkin, Sovereign Virtue (Cambridge, MA: Harvard University Press, 2000) ch 3, 4; John Roemer, "A Pragmatic Theory of Responsibility for the Egalitarian Planner" (1993) 22 Philosophy \& Public Affairs 146; Rosanvallon, supra note 60; Samuel Scheffler, "What Is Egalitarianism?' (2003) 31 Philosophy \& Public Affairs 5.

82 In addition to the equal treatment clause of the Fourteenth Amendment, we must include ss 15(1) and 28 of the Canadian Charter of Rights and Freedoms, infra note 89; art 14 of the Indian Constitution; s 1-4 and schedule 1 of the Human Rights Act 1998, 1998, c 42, alongside art 14 of the ECHR, supra note 16; and s 8 of both the Human Rights Act 2004, Act no A2004-5; Victoria Charter of Human Rights and Responsibilities Act 2006, Act no 43/2006. 
and the constitutional and related provisions that trigger it, is what I mean by "the argument from equality." ${ }^{83}$ Can arguments of this type support an entitlement to access to justice?

There is no reason why, in principle, they cannot. But the juridical statements of equality from which such arguments begin are more problematic than is often appreciated, principally because they provide little guidance as to the nature of equality and inequality. Although some laws, policies, procedures, and forms of conduct are now clearly invalid under these provisions (such as, for example, the enactment of a legal provision explicitly favouring Caucasians and disadvantaging non-Caucasians), there are nevertheless many instances in which it is hard to be certain. ${ }^{84}$ At least, this is so if we have reference to nothing more that the wording of these provisions themselves. Thus, it is simply unclear from the equal protection clause of the Fourteenth Amendment, for example, whether or not University of Michigan Law School admission procedures, which in some instances prioritize factors in addition to academic merit, deny some citizens equal protection of the laws. It is similarly far from obvious whether equivalent broad equality provisions in other jurisdictions permit, for instance, differential access to public spaces, schooling, and legal advice or differential levels of social security benefits. ${ }^{85}$ In all but the most blatant cases, the courts must necessarily go beyond the literal wording of the relevant equality provisions, in part because of the distance between these general statements ("every individual is equal before and under the law") and specific legal questions (is it discriminatory for the province of Quebec to pay the young unemployed less in benefits than their unemployed elders?). Since the words of this and similar equality provisions give little guidance as to how to decide particular cases, something more is therefore necessary than recourse to the bare text. What is this "more" and, further, what informs the search for it, gives it traction?

If the provision in question has been litigated before, then the precedents may provide some guidance. So, too, might the legislative history of the provision, but there is no guarantee that it will

83 In the US context, the due process and equal treatment clauses of the Fourteenth Amendment both play a role in relation to access to justice, but I set the former aside. Not all jurisdictions with general equality provisions have a similar due process clause. On due process arguments generally, see Michelman, supra note 1, and US Supreme Court decision in Turner, supra note 13; on some of the interconnections between the two clauses, see Kenji Yoshino, "The New Equal Protection" (2011) 124 Harv L Rev 747. Some instances of the equality argument are Rhode, supra note 6, ch 1; Earl Johnson, Jr, \& Elizabeth Schwartz, "Beyond Payne: The Case for a Legally Enforcible Right to Representation in Civil Cases for Indigent California Litigants Part One: The Legal Arguments" (1977-1978) 11 Loyola LA L Rev 249 at 278295; MJ Mossman, with Karen Schucher \& Claudia Schmeing, "Comparing and Understanding Legal Aid Priorities: A Paper Prepared for Legal Aid Ontario” (2010) 29 Windsor Rev Legal Society Issues 149 at 187-188; MF Davis, "Participation, Equality, and the Right to Civil Counsel: Lessons from Domestic and International Law" (2013) 122 Yale LJ 2260 at 2268-2270. For what seems to be a sceptical response to the equality argument but is not, see Philip Lewis, "Unmet Legal Needs" in Pauline Morris, Richard White \& Philip Lewis, eds, Social Needs and Legal Action (London: Martin Robertson, 1973) 73 at 75-79.

84 The key word in the first clause of this sentence is "now"; for the history of the Fourteenth Amendment see William Nelson, The Fourteenth Amendment: From Political Principle to Judicial Doctrine (Cambridge, MA: Harvard University Press, 1988) chs 1, 7, 8; Alexander Bickel, "The Original Understanding and the Segregation Decision" (1955) 69 Harv L Rev 1.

85 A smattering of the vast number of cases: Grutter $v$ Bollinger, 539 US 306 (2003) (US SC) (access to law school and the Fourteenth Amendment); Gosselin v Quebec (AG), [2002] 4 SCR 429 (SC Can) [Gosselin] (differential welfare benefits and s 15 of the Canadian Charter); ECtHR, Baczkowski and Others v Poland, Appl no 1543/06 (3 May 2007) (art 14, inter alia, of ECHR and permission for public gathering). 
include anything salient. Furthermore, even textual sources like precedents and legislative history will rarely rationally compel a particular interpretation of an equality provision in a specific case. This is because such additional textual evidence is itself usually subject to a process of elaboration or interpretation. Consider, for example, what common law appellate courts usually do with precedents cited to them as a guide to the meaning of some or other equality provision. Whether or not such precedents are factually close, they are usually examined (1) with a view to the light they cast upon the meaning of the provision; (2) with a view to the sense they make of adjacent precedents and legal provisions; and (3) with a view to their implications in the case at bar and for the future of the area of law in question. Particular precedents might be found satisfactory or unsatisfactory on one or more dimensions. This process is clearly anything but automatic, leaving room for different judgments about "sense" and "implications" and, thus, never determined solely by the precedent(s) cited. If the precedents were indeed determinative in this "self-interpreting" way, then the case would not be "hard" and would therefore not be litigated. ${ }^{86}$

Moreover, when "the meaning of the provision" is sought, either in precedents or in other textual sources, what exactly is being sought? The words of the provision are there in the text, so how can its "meaning" reside elsewhere? And when the implications of applying a precedent to the case at bar are determined to be either good or bad, how is that judgment arrived at? The answer is that the meaning sought, and the basis for judging implications to be good, bad, or indifferent, is found, as many lawyers would now say, in "a theory" of the provision in question, by which they mean an account of its point, purpose, or value. ${ }^{87}$ The process of elaboration in the interpretation of juridical equality provisions is thus one that involves both descent, moving from the general provision to the particular case, and ascent, moving from the general provision to an account of its point, purpose, or value. Both aspects of this process are connected in that "the theory" of the provision indicates the interpretative pathways along which to proceed in particular cases. Note, though, that such theories are not rightly viewed as being more abstract than the provisions they theorize. Rather, they usually serve to make those provisions more specific, both in terms of an account of their point, purpose, or value and in terms of what that account requires in particular cases. Such a theory gives the provision "depth," showing us how to go on applying it, and is thus not best regarded as being solely abstract. ${ }^{88}$

86 On what makes a hard case hard, see the slightly different views in Neil MacCormick, Legal Reasoning and Legal Theory, revised ed (Oxford: Clarendon Press 1978, 1994) at 65-72, ch 6-8; Ronald Dworkin, Taking Rights Seriously (London: Duckworth, 1977) at 81. MacCormick's original view must now be supplemented by Neil MacCormick, Rhetoric and the Rule of Law (Oxford: Clarendon Press, 2005) at 49-52.

87 Although this process is described differently by jurists in various jurisdictions, its substance is at root the same. For the process with regard to the Fourteenth Amendment of the US Constitution, see Joseph Trusman \& Jacobus tenBroek, "The Equal Protection of the Laws" (1949) 37 California L Rev 341; Owen Fiss, "Groups and the Equal Protection Clause" (1976) 5 Philosophy \& Public Affairs 107; Laurence Tribe, American Constitutional Law, 2d ed (New York: Foundation Press, 1988) vol 2, ch 16. For the interpretation of equality provisions in the Canadian Charter, see Brudner, supra note 4 at 131-142; David Beatty, The Ultimate Rule of Law (New York: Oxford University Press, 2004) ch 3; Robert Sharpe et al, The Charter of Rights and Freedoms, 3d ed (Toronto: Irwin Law, 2005) ch 15. An interesting treatment of the approach of the European Court of Human Rights is George Letsas, A Theory of Interpretation of the European Convention on Human Rights (Oxford: Clarendon Press, 2007) ch 3, 5.

88 On the idea of "knowing how to go on' and its complications (which are ignored above), see Ludwig Wittgenstein, Philosophical Investigations, 2d ed (Oxford: Blackwell, 1958) 1, paras 143-242. 
The open-ended nature of juridical equality provisions, conjoined with the process of elaboration involved when the courts apply them in all but the simplest of cases, warrants two claims. First, that there is no in-principle barrier preventing these provisions providing a normatively compelling case for all three components of access to justice. However, the job of constructing such a case is neither an easy nor a direct one, the distance from these provisions to an entitlement to access to justice being just as far, and just as contestable and problematic, as that from such provisions to, for example, a decision about the legitimacy of differential welfare payments.

This point might explain the second claim, which is that these provisions have never been successfully invoked to justify a full entitlement to access to justice. This is certainly so in two jurisdictions with such provisions, namely Canada and the United States. In Canada, section 15(1) of the Canadian Charter of Rights and Freedoms has played no role in the most recent access to justice cases, and some have suggested that the attempt to invoke this provision as a base for an entitlement to access to justice is a mistake. ${ }^{89}$ The principal problem is that claimants need to show that a particular denial of access to justice was the result of treatment on those prohibited (or analogous) grounds noted in the Charter and that indigence is not such a ground. ${ }^{90}$ Thus, the elements of an entitlement to access to justice protected by Canadian law, like the LF and LE components, are secured not by the equality argument but, rather, by reference to other legal provisions, such as section 96 of the Constitution Act 1867. ${ }^{91}$ The LK component has, so far as I am aware, received no independent attention in cases under section 15(1) of the Charter.

In the United States, the equal protection clause has not been conspicuously effective in supporting an entitlement to access to justice. It has partially upheld the LE component, having been invoked to support a limited right to counsel in civil cases, the limitation being determined by reference to the importance of the interest at stake. ${ }^{92}$ The position is much the same with regard to the LF component, the US Supreme Court having said that court-related fees, like those for transcripts, can in some circumstances breach the equal protection clause. ${ }^{93}$ As to the LK component, this seems only ever to be addressed insofar as it can be subsumed under the LE component. The equal protection clause thus does not support a general entitlement to access to justice.

As things stand, the equality provisions in these jurisdictions do not provide a normatively compelling case for a full entitlement to access to justice. Can the argument from non-domination do better? A strict comparison is impossible, there being no constitutions with non-domination provisions. But the argument from non-domination offered above does indeed get down to cases and makes a clear argument in favour of each component of access to justice, which was part of the rationale for focusing

89 See Trial Lawyers, supra note 13; Hryniak, supra note 67. Canadian Charter of Rights and Freedoms, Part 1 of the Constitution Act, 1982, being Schedule B to the Canada Act 1982 (UK), 1982, c 11 [Charter].

90 The point belongs to MB Rankin, "Access to Justice and the Institutional Limits of Independent Courts" (2012) 30 Windsor YB Acc Just 101 at 110-111; see also Gosselin, supra note 85.

91 Constitution Act, 1867, (UK), 30 \& 31 Vict.

92 See Lassiter, supra note 13; Turner, supra note 13.

93 MLB v SLJ, 519 US 102 (1996). 
upon the hypothetical cases. And this shows that the argument satisfies the determinacy assumption. The argument from equality has not yet satisfied that assumption, but particular versions of it might. ${ }^{94}$

\begin{abstract}
$* * *$
In lieu of a conclusion, I make explicit two implicit challenges that inform this article. One may appear absurdly utopian - it invites us to imagine a world in which our elected representatives attend to articles like this when formulating policy positions on matters of legal-institutional design. ${ }^{95}$ In a political world in which evidence-based policy making has seemingly been rejected, a call for explicitly normatively informed policy making also seems doomed. Stranger things, however, have happened. ${ }^{96}$ The second challenge is to that supposedly sensible and pragmatic form of hard-headedness that many elected representatives, policy makers and others affect, which holds that, since we live in financially and fiscally troubled times, "belts must be tightened," public spending cut, tough choices made. If the choice for the use of tax dollars is either heart operations for sick children or finance for free legal advice centres, then the former must win. ${ }^{97}$ This supposed hard-headedness converts political choices - since 2008 , the choice of fiscal austerity and public spending reductions - into natural necessities. We might well have tough choices to make, but this needs be shown rather than assumed. Furthermore, we will appreciate the true difficulty of the choices we face only if we understand the stakes and values in play. This article has sought to show what is at stake when access to justice is denied or undermined.
\end{abstract}

94 Thus, supreme courts in various US states have gone beyond the US Supreme Court in founding a robust entitlement to access to justice upon their own constitutional equivalents to the Fourteenth Amendment. See Johnson and Schwartz, supra note 83 at 278-290; Davis, supra note 83 at 2270-2274.

95 There have been many commissions, committees of inquiry, working parties, and so on into various aspects of access to justice over the last thirty years in all of the common law jurisdictions. These bodies spend little time addressing that idea's normative basis. See Macdonald, supra note 7, for an insight and, for an exception, Dyzenhaus, supra note 5.

96 See JL Marti \& Philip Pettit, A Political Philosophy in Public Life: Civic Republicanism in Zapatero's Spain (Princeton, NJ: Princeton University Press, 2012).

97 See Macdonald, supra note 7 at 292, for an instance; an echo of the view is AAS Zuckerman, "Human Rights and the Costs of Justice," Letter, The Guardian (10 November 2015), online:

$<$ https:/www.theguardian.com/law/2015/nov/10/human-rights-and-the-cost-of-justice >: "Resource limitation is an integral part of any public service." 